ks. Wojciech Medwid ${ }^{1}$

Uniwersytet Papieski Jana Pawła II w Krakowie

\title{
Marcin Bucer jako pionier reformacyjnego pojednania
}

Ruch reformacyjny, zapoczątkowany w XVI wieku przez Marcina Lutra, zrodził wielkich krajowych reformatorów, którzy starali się wprowadzić odnowę chrześcijaństwa. Każdy z nich miał własną wizję „nowego porządku" praktyk, jak i doktryny Kościoła. Można wymienić słynne postaci szesnastowieczne, takie jak: wspomniany Marcin Luter, Jan Kalwin, Huldrych Zwingli, Filip Melanchton, Tomasz Münzer czy król Henryk VIII. Mniej znanym reformatorem był Marcin Bucer (Butzer), którego postać i działalność związane były ze Strasburgiem. Celem artykułu jest ukazanie pod względem doktrynalnym i organizacyjnym dążeń Marcina Bucera do zapobieżenia (poprzez mediację) rozłamowi między dwoma wiodącymi reformatorami - Marcinem Lutrem i Huldrychem Zwinglim oraz pojednania protestantów z katolikami. Pod tym względem stał się niejako „ekumenistą". Bliższe przyjrzenie się poczynaniom Bucera pozwoli na przedstawienie jego życiowej misji, której był pionierem i którą chciał zrealizować za wszelką cenę, oraz na dostrzeżenie terenów jego oddziaływania w dobie reformacji.

1 Medwid Wojciech - doktor, kapłan diecezji bielsko-żywieckiej Kościoła rzymskokatolickiego, absolwent Wydziału Teologicznego Uniwersytetu Papieskiego Jana Pawła II w Krakowie, obecnie pracuje w parafii św. Klemensa w Ustroniu. 


\section{Młodość i zerwanie z Kościołem katolickim}

Dzieciństwo i dorastanie Marcina Bucera było związane z miastem Schlettstadt (Sélestat) w Alzacji (obecnie Francja), gdzie urodził się 11 listopada 1491 roku. W rodzinnym mieście uczęszczał do prestiżowej łacińskiej szkoły, do której rzemieślnicy posyłali swoje dzieci. Jego ojciec i dziadek zajmowali się wyrobem drewnianych naczyń, natomiast prawie nic nie wiadomo o jego matce. Po skończonych studiach (1507) jako nowicjusz wstąpił w Strasburgu do zakonu dominikanów. Twierdził później, że to dziadek zmusił go do podjęcia tej decyzji. Po roku został wyświęcony na akolitę i złożył śluby zakonne, a w roku 1510 został wyświęcony na diakona. Studiował teologię w klasztorze dominikanów w Heidelbergu i dogmatykę w Moguncji, gdzie został wyświęcony na kapłana. Następnie zapisał się na uniwersytet w Heidelbergu. W tym czasie „zaprzyjaźnił się” z renesansowym humanizmem. Zaczął nabywać i czytać dzieła wydane przez Johannesa Frobena, a szczególnie przez ikonę humanizmu, Erazma z Rotterdamu. W 1518 roku Jan Staupitz, generalny wikariusz augustianów, zwrócił się do Lutra, aby zajął się argumentacją swojej teologii w dyspucie w Heidelbergu. Tam Bucer po raz pierwszy spotkał ojca reformacji. Komentując kilka z jego 95 tez, w znacznej mierze podzielał ich treść, dochodząc do przekonania, że idee Lutra i Erazma nie są ze sobą sprzeczne. Na początku 1519 roku uzyskał stopień baccalaureusa, a latem oświadczył, że jego dotychczasowe poglądy teologiczne mijają się z nauką św. Tomasza z Akwinu i scholastyką, z którą niniejszym zerwał².

Nowe pomysły i pogłębiające się relacje Bucera z innymi reformatorami i humanistami oraz wydarzenia z udziałem tych ostatnich poskutkowały opuszczeniem zakonu dominikanów. Jego znajomy dominikanin, wielki inkwizytor z Kolonii Jakub Hoogstraaten, groził mu, że uczyni z niego przykład zwolennika Lutra. Wolfgang Capito skutecznie pomógł Bucerowi uzyskać zwolnienie ze ślubów zakonnych i tym samym został formalnie wydalony z zakonu dominikanów. Zaś schronienie znalazł u Franza Sickingena (wysoki urzędnik na dworze Ludwika, jedna z najbardziej znaczących postaci pierwszego okresu reformacji) i Ulricha von Huttena (zagorzały krytyk Kościoła ka-

\footnotetext{
Por. M. Greschat, Martin Bucer: a reformer and his times, Kentucky 2004, s. 10-29; H. Selderhuis, Marriage and divorce in the thought of Martin Bucer, Missouri 1999, s. 51-55.
} 
tolickiego i porozumienia między humanistami a kontrowersją luterańską). Przez pewien czas pracował także na dworze Ludwika V, elektora Palatynatu, jako kapelan młodszego brata Ludwika, Fryderyka. Nominacja ta pozwoliła mu zamieszkać w Norymberdze, najpotężniejszym mieście Cesarstwa (nazywanym nieoficjalnie jego stolicą). Poznał tam wielu ludzi, którzy podzielali jego punkt widzenia, w tym humanistę Willibalda Pirckheimera i przyszłego norymberskiego reformatora Andreasa Osiandera. W 1521 roku Bucer za przyczyną Sickingena został proboszczem w Landstuhl, gdzie ten ostatni miał zamek. Rok później poznał i poślubił Elżbietę Silbereisen, byłą zakonnicę ${ }^{3}$.

Sickingen, widząc w Bucerze swojego poplecznika, zaproponował mu sfinansowanie studiów w Wittenberdze. Po drodze Bucer zatrzymał się w Wissembourgu, którego głównym reformatorem był Heinrich Motherer. Ten poprosił go, aby został jego kapelanem. Bucer bez wahania przerwał podróż i rozpoczął nową pracą. W codziennych kazaniach piętnował tradycyjne praktyki kościelne i zakonne. Przekonany, że Biblia jest jedynym źródłem wiedzy do osiągnięcia zbawienia (sola Scriptura), głosił, że msza święta nie powinna być postrzegana jako ponowne ukrzyżowanie Chrystusa, ale raczej jako przyjęcie Bożego daru - zbawienia przez Chrystusa. Ponadto oskarżał lokalnych franciszkanów i dominikanów o tworzenie dodatkowych przepisów ponad to, co jest zawarte w Biblii, i wzywał ich do publicznej debaty. Ci jednak zignorowali go. W swych kazaniach podburzał również mieszczan, sugerując, że klasztory stanowią zagrożenie dla miasta. Został za to ekskomunikowany przez Jerzego, biskupa Speyer. Z kolei jego czołowy dobroczyńca Franz Sickingen został pokonany i zabity podczas rycerskiego buntu, a Ulrich von Hutten stał się zbiegiem. Rada Wissembourgska wymogła na Bucerze i Mothererze opuszczenie miasta. W 1523 roku oboje uciekli do pobliskiego Strasburga ${ }^{4}$. Początek działalności reformatorskiej Marcina Bucera był dosyć chaotyczny. Bazując na poglądach Lutra, próbował promować swoją osobę.

3 Por. D. Lawrence, Martin Bucer: unsung hero of the Reformation, Nashville 2008, s. 35-47; H. Selderhuis, Marriage and divorce in the thought of Martin Bucer, dz. cyt., s. 116-117; M. Greschat, Martin Bucer: a reformer and his times, dz. cyt., s. 29-40.

${ }^{4}$ Por. D. MacCulloch, Reformation: Europe's house divided, London 2003, s. 157-160; M. Greschat, Martin Bucer: a reformer and his times, dz. cyt., s. 40-45. 


\section{Misja reformatorska w Strasburgu}

Głównym miejscem działalności reformatorskiej Bucera stał się Strasburg, do którego przybył jako ekskomunikowany i bez środków do życia. Jego sytuacja była trudna: nie był obywatelem miasta, czyli nie miał statusu, który zapewniałby mu ochronę. Napisał list do Zurychu do Huldrycha Zwinglego, błagając go o zabezpieczenie pobytu w Szwajcarii. Na szczęście rada Strasburga była pod wpływem obiecującego reformatora Mateusza Zella i przyjęła jego wniosek o przyznanie obywatelstwa Bucerowi. Ten początkowo pracował w mieście jako nieoficjalny kapelan Zella i prowadził zajęcia na temat Biblii. W Strasburgu dołączył do grupy wybitnych reformatorów: Mateusza Zella, który objął funkcję kaznodziei mszalnego, Wolfganga Capito - najbardziej wpływowego teologa w mieście i Caspara Hedio, kaznodziei katedralnego. Jednym z pierwszych posunięć w sprawach reformy była dyskusja z Tomaszem Murnerem, energicznym mnichem, który wszędzie widział wrogów i w swoich satyrach ostro atakował korupcję swoich czasów, ruch reformacyjny, a zwłaszcza Marcina Lutra. Choć rada wahała się co do kwestii religijnych, to wciąż wzrastała liczba osób popierających reformację i wrogich wobec tradycyjnego duchowieństwa. Wrogość osiągnęła apogeum, kiedy Konrad Treger, prowincjał augustianów, potępił reformatorskich kaznodziejów i mieszczan Strasburga i uznał ich za heretyków. Wielu przeciwników reformacji zostało aresztowanych, w tym Treger. Po tych wydarzeniach rada miasta Strasburga zwróciła się o oficjalne oświadczenie ze strony reformatorów. Bucer sporządził dwanaście artykułów podsumowujących naukę reformacji, w tym „usprawiedliwienie przez wiarę" (sola fide). Odrzucił mszę świętą, śluby zakonne, cześć świętych i czyściec. Odmówił także uznania autorytetu papieża, a zamiast tego podkreślał posłuszeństwo wobec sprawujących władzę świecką. Treger został uwolniony i opuścił Strasburg. Wraz z jego wyjazdem zakończyła się w mieście jawna opozycja wobec reformacji ${ }^{5}$.

Pierwszym celem reformatorów było stworzenie nowego rytu mszy świętej. Dotychczas w Strasburgu wzorowano się na liturgii Huldrycha Zwinglego. Reformatorzy przedstawili teologom w Wittenberdze i Zurychu propozy-

Por. J. Todd, Reformacja, przekł. T. Szafrański, Warszawa 1974, s. 287-289; M. Greschat, Martin Bucer: a reformer and his times, dz. cyt., s. 54-62. 
cję wspólnego rytu mszy dla całego ruchu reformacyjnego. W broszurze Grund und Ursach ${ }^{6}$ opublikowanej w grudniu 1524 roku Bucer zaatakował ideę mszy jako ofiary i odrzucił szaty liturgiczne, ołtarz oraz każdą formę rytuału. Powyższe postulaty zostały wdrożone w kościołach parafialnych Strasburga, ale rada miejska pozwoliła na dalsze odprawianie mszy świętych w katedrze i w kolegiatach św. Tomasza i św. Piotra7

\section{Między Marcinem Lutrem a Huldrychem Zwinglim}

Doświadczenia z pobytu w Strasburgu zaowocowały tym, że Bucer nabrał pewności siebie i od razu mocno zaangażował się w ważne sprawy doktrynalne reformacji. Od roku 1524 koncentrował się na głównej kwestii podziału czołowych reformatorów, czyli na Eucharystii. Próbował pośredniczyć między Lutrem i Zwinglim, chcąc doprowadzić do zawarcia między nimi pokoju. Teologowie ci mieli rozbieżne zdania w kwestii, czy podczas celebracji Wieczerzy Pańskiej Ciało i Krew Chrystusa są prawdziwie obecne w postaciach chlebai wina? Luter wierzył w rzeczywistą, natomiast Zwingli w symboliczną obecność Chrystusa. Bucer porzucił ideę rzeczywistej obecności, a po wielu egzegetycznych badaniach przyjął interpretację Zwinglego. Jednak nie wierzył, że reformacja uzależniona była od obu pozycji. Fundamentem jest wiara w Chrystusa, a inne sprawy są drugorzędne. Podkreślał, że większe znaczenie należy przyłożyć do upamiętnienia śmierci Jezusa niż do odpowiedzi na pytanie, co się je i pije. W tym względzie różnił się od Zwinglego .

Formą obrony swoich poglądów było opublikowanie przez Bucera Apologii`. Miał głęboką nadzieję, że zadowoli obie strony sporu, i zaproponował formułę: można zaakceptować różne rozumienie Pisma, a jedność Kościoła jest zapew-

6 Por. M. Bucer, Grund und Ursach auß gotlicher Schrifft der Neuerungen an dem Nachtmal des Herren so man die Mess nennet, [w:] Martin Bucers Deutsche Schriften, Bd. 1, hg. R. Stupperich, Gütersloh-Paris 1960, s. 194-278.

Por. M. Greschat, Martin Bucer: a reformer and his times, dz. cyt., s. 63-63.

8 Por. C. Krieger, Martin Bucer and sixteenth century Europe, Leiden 1993, s. 395-401; M. Greschat, Martin Bucer: a reformer and his times, dz. cyt., s. 72-74.

9 Por. Martini Buceri Apologia qua fidei suae atque doctrinae, [w:] Martin Bucers Deutsche Schriften, Bd. 2, hg. R. Stupperich, Gütersloh-Paris 1962, s. 452-524. 
niona, jeśli obie strony będą miały dziecięcą wiarę w Boga. Ponadto zaznaczył, że prawidłowa jest jego i Zwinglego interpretacja Eucharystii. Jednoczenie uważał, że teologowie z Wittenbergi są w błędzie. Ci zaś oburzyli się i zerwali $\mathrm{z}$ nim kontakty. Gdy Luter opublikował Vom Abendmahl Christi, Bekenntnis ${ }^{10} \mathrm{z}$ wyszczególnieniem koncepcji unii sakramentalnej, Bucer odpowiedział swoim traktatem Vergleichnung D. Luthers, und seins gegentheyls i vom Abendmal Christi ${ }^{11}$. Był to dialog między dwoma kupcami, jednym z Norymbergi, który popierał Lutra, i drugim ze Strasburga, który był po stronie Bucera. Rozmowa została tak skonstruowana, że ten ostatni odniósł zwycięstwo nad swoim oponentem. Bucer zauważył, że ponieważ Luter odrzucił ideę, iż Chrystus przemienił się w chleb, to nie może być zgody pomiędzy ojcem reformacji a Zwinglim. Oboje wierzyli w duchową obecność Chrystusa w Eucharystii. Luter kategorycznie odrzucił interpretację Bucera. W tych okolicznościach relacje reformatora ze Strasburga i Zwinglego zacieśniły się; postanowili omówić inne aspekty teologii i praktyki, takie jak używanie obrazów religijnych i liturgia. Następnie Bucer i Capito uczestniczyli w debacie w Bernie, gdzie mieli zdecydować, czy miasto powinno przyjąć zreformowaną doktrynę i praktyki. Bucer dostarczył silnego wsparcia dla przywódczej roli Zwinglego w tej dyskusji, która w końcu doprowadziła do reformacji w Bernie. Ostatnie spotkanie Zwinglego i Lutra miało miejsce podczas rozmów w Marburgu (październik 1529) zorganizowanych przez Filipa Heskiego, z udziałem różnych wiodących reformatorów, w tym także Bucera. Luter i Zwingli uzgodnili 13 z 14 poruszanych kwestii, jednak ten drugi nie przyjął doktryny o realnej obecności, co do której Luter nie poszedłby na kompromis. Po tej dyskusji relacje między nimi uległy pogorszeniu. Bucer próbował ratować sytuację, ale Luter zauważył, że jest sprawą oczywistą, że nie mają jednego i tego samego ducha. Ostatecznie spotkanie zakończyło się niepowodzeniem ${ }^{12}$.

Skala teologicznego podziału wśród reformatorów stała się jasna, kiedy cesarz Niemiec Karol V poprosił ich, aby przedstawili mu swoje opinie na

10 Por. M. Luther, Vom Abendmahl Christi, Bekenntnis, [w:] Martin Luthers Werke. Kritische Gesammtausgabe, Weimar 1883-1929, Bd. 26, s. 261-509.

${ }_{11}$ Por. M. Bucer, Vergleichnung D. Luthers, und seins gegentheyls, vom Abendmal Christi, [w:] Martin Bucers Deutsche Schriften, Bd. 2, dz. cyt., s. 527-563.

12 Por. M. Edwards, Luther and the False Brethren, Standford 1975, s. 93-98; M. Greschat, Martin Bucer: a reformer and his times, dz. cyt., s. 74-94. 
sejmie w Augsburgu (1530). Filip Melanchton, główny delegat z Wittenbergi, szybko przygotował projekt, który w rezultacie stał się Wyznaniem augsburskim $^{13}$. Kopia tego dokumentu była używana jako punkt wyjścia, a główną zmianą było sformułowanie na temat Eucharystii. Teologowie wittenberscy odrzucili próby podejmowane przez Strasburg, aby przyjąć je bez artykułu o Wieczerzy Pańskiej. W odpowiedzi Marcin Bucer (z dużą pomocą Wolfganga Capito) napisał nowe wyznanie, Confessio tetrapolitana ${ }^{14}$. Nazwa tego dokumentu została utworzona $\mathrm{z}$ dwóch greckich słów: tetra-cztery oraz polis - miasto - tylko cztery miasta przyjęły Confessio: Strasburg i trzy południowe miasta niemieckie: Konstancja, Memmingen i Lindau. Można tu zauważyć pewną determinację Bucera do osiągnięcia teologicznego konsensusu w palącej kwestii obecności Chrystusa w elementach Eucharystii. Poczynił on istotne ustępstwa co do biblijnej prawdy w nadziei, że luteranizm i kalwinizm skupią się na tej jednej kwestii, która ich dzieli. Niejednokrotnie stosował niejasne i niejednoznaczne formuły. Swoje postępowanie usprawiedliwiał, twierdząc, że podstawowym celem jest reforma ludzi, a kwestie doktrynalne mogą być opracowane w dalszej kolejności ${ }^{15}$.

Karol postanowił jednak, że wszyscy reformatorzy muszą pogodzić się z wiarą katolicką. To skłoniło Filipa Melanchtona do spotkania z Bucerem. Po długich dyskusjach zgodzili się na dziewięć tez, które wysłali do Lutra i do Strasburga. Sędziowie w Strasburgu przekazali je do Bazylei i Zurychu. Spotkawszy Lutra w Coburgu, Bucer nieustannie zachęcał go do kontynuowania poszukiwania jedności. Tezy reformatora ze Strasburga wciąż były dla niego nie do przyjęcia. Następnie Bucer udał się do kilku południowych niemieckich miast, m.in. Ulm, Isny, Konstancji, Memmingen i Lindau, oraz do szwajcarskich: Bazylei i Zurychu, aby nakłonić protestantów do przygotowania deklaracji, która spełniałaby wymagania Lutra. W Zurychu przedstawił Zwinglemu artykuły, które nie sprzeciwiały się mu ani go nie popierały. W 1531 roku ewangeliccy książęta i miasta cesarstwa utworzyli

13 Por. F. Melanchton, Confessio Augustana, [w:] Die Bekenntnisschriften der evangelisch-lutherischen Kirche, hg. im Gedenkjahr der Augsburgischen Konfession 1930, Göttingen 1998, s. 31-137.

14 Por. M. Bucer, Confessio Tetrapolitana, [w:] Martin Bucers Deutsche Schriften, Bd. 3, hg. R. Stupperich, Gütersloh-Paris 1969, s. 187-318.

${ }_{15}$ Por. Reformed confessions of the sixteenth century, ed. A. Cochrane, J. Rogers, London 2003, s. 51-88; J. Todd, Reformacja, dz. cyt., s. 250. 
protestancką Ligę szmalkaldzką, aby bronić zreformowanej religii. W tym czasie pogarszały się coraz bardziej relacje Bucera ze Zwinglim. Polityczne więzi Strasburga z elektorem Saksonii, jak i częściowe poparcie teologiczne Bucera przez Lutra były nie do przyjęcia dla Zwinglego - ich przyjaźn oficjalnie się zakończyła. Kiedy przedstawiciele południowych miast niemieckich spotkali się w Ulm (23-24 marca 1532) w celu omówienia sojuszu z Ligą szmalkaldzką, Bucer mocno nakłaniał ich do podpisania Wyznania augsburskiego. Wielkim zaskoczeniem dla miast Szwajcarii było wychwalanie przez Bucera innego confessio ponad swoje własne. Luter kontynuował swoje polemiczne ataki wymierzone w Bucera, ale ten pozostał niewzruszony. Tu znów można dostrzec dążenie do porozumienia za wszelką cenę. Bucer podkreślał mimo wszystko, że trzeba szukać jedności i miłości w relacjach z każdym, niezależnie od tego, jak zachowuje się wobec nas. W 1533 roku ponownie odwiedził południowe miasta niemieckie i szwajcarskie. Te ostatnie pozostały nieprzekonane i nie przyłączyły się do protestanckiego sojuszu ${ }^{16}$.

\section{Tworzenie strasburskiego Kościoła}

Skuteczne wprowadzanie reform można dostrzec na przykładzie Strasburga. Reformatorzy powoli robili postępy, mocno naciskając na radę miejską, aby zakazano w mieście wszystkich mszy. W końcu rada uległa presji i praktyka mszy została oficjalnie zawieszona, a Strasburg otwarcie przyłączył się do reformacji. We wszystkich kościołach parafialnych w miejsce niedzielnej Eucharystii odbywały się „nabożeństwa przepowiadania słowa” (Predigtgottesdienste). Z początkiem 1530 roku, kiedy to Strasburg dołączył do sojuszu szwajcarskich miast (Christliches Burgrecht), rada sukcesywnie usuwała obrazy i ołtarze boczne z kościołów. Bucer początkowo przymykał oczy na obrazy w miejscach kultu, o ile nie były one czczone. Później jednak doszedł do wniosku, że powinny być całkowicie usunięte ze wzglę-

16 Por. D. MacCulloch, Reformation: Europe's house divided, dz. cyt., s. 200; M. Hughes, Early Modern Germany, London 1992, s. 55-56; P. Collinson, The Reformation, London 2003, s. 131; M. Greschat, Martin Bucer: a reformer and his times, dz. cyt., s. 95-101. 
du na możliwości ich nadużywania, a wierni mają zaprzestać praktykowaniu kultu obrazów ${ }^{17}$.

Priorytetem Marcina Bucera w Strasburgu było zaszczepienie moralnej dyscypliny w Kościele. W tym celu spośród wiernych zostali wybrani specjalni strażnicy Kościoła (Kirchenpfleger), których przypisano do poszczególnych kongregacji, aby nadzorować zarówno doktrynę, jak i praktykę. Takie postępowanie uzasadnione było widocznymi skutkami nagłego wzrostu populacji uchodźców, zwabionych tolerancyjną polityką Strasburga jako azylu. Napływający banici zasilili szeregi rewolucyjnych kaznodziejów w mieście. Zainspirowali się oni wielością doktryn apokaliptycznych i mistycznych, a w niektórych przypadkach wrogością wobec porządku społecznego i pojęcia Kościoła. Znaczna liczba uchodźców była anabaptystami i spirytystami. Można wymienić znaczące postaci, takie jak: Melchior Hoffman, Caspar Schwenckfeld i Clemens Ziegler. Bucer wziął na siebie odpowiedzialność za pojawiających się rewolucyjnych kaznodziejów w celu zminimalizowania ich wpływu oraz aby zapewnić wydalenie ich wraz z ich zwolennikami. Proboszczowie i administratorzy Kościoła przedłożyli radzie petycję z trzema postulatami. Po pierwsze, aby wzmocniono etyczne standardy; po drugie, aby oficjalnie usankcjonowano zreformowaną wiarę i po trzecie, aby obalono sekciarskie doktryny. Rada miasta Strasburga z jednej strony zaplanowała wypędzenie intrygantów, a z drugiej pozwoliła rozwijać się sekciarskim grupom wśród uchodźców i niższych klas społecznych. Bucer zaapelował, aby dla dobra wspólnego w trybie pilnym przejęła kontrolę nad całym chrześcijańskim kultem w mieście. W odpowiedzi na petycję rada powołała komisję, która zwołała synod miasta. Na tym spotkaniu Bucer przedstawił projekt dokumentu szesnastu artykułów na temat doktryny kościelnej. 3 czerwca 1533 roku synod w kościele św. Marii Magdaleny ostatecznie przyjął go w całości. Sekciarscy przywódcy stanęli przed synodem i byli przesłuchiwani przez Bucera. Clemens Ziegler został usunięty, ale mógł przebywać w Strasburgu; Melchiora Hoffmanna uwięziono i uznano za zagrożenie dla państwa, a Caspar Schwenckfeld opuścił Strasburg z własnej woli ${ }^{18}$.

17 Por. C. Eire, War against the idols, Cambridge 1989, s. 93-94.

18 Por. D. Lawrence, Martin Bucer: unsung hero of the Reformation, dz. cyt., s. 22-28; M. Greschat, Martin Bucer: a reformer and his times, dz. cyt., s. 117-122. 
Komisja synodalna, której członkami byli Bucer i Capito, postanowiła przejąć inicjatywę i stworzyć projekt zarządzania Kościołem. Chciano, aby rada miała niemal całkowitą kontrolę nad Kościołem, brała odpowiedzialność za nadzór nad doktryną, powoływała strażników kościołów i stała na straży standardów moralnych. Władze miasta poinformowały, że Confessio tetrapolitana Bucera i jego szesnaście artykułów dotyczących doktryny Kościoła stały się oficjalnym kościelnym oświadczeniem w sprawie wiary. Wszyscy anabaptyści powinni albo podpisać się pod tymi dokumentami, albo opuścić miasto. Decyzją tą ustanowiono nowy ustrój kościelny w mieście. Można powiedzieć, że w Strasburgu Marcin Bucer rozwinął skrzydła jako propagator reformy protestanckiej. Pragnął, aby wprowadzony nowy porządek był całkowicie po jego myśli. Dopiero po czasie przekonywał się do propozycji innych ${ }^{19}$.

\section{Dążenia do protestanckiej jedności}

Nie będzie kłamstwem stwierdzenie, że czas od połowy lat 30. XVI wieku upłynął pod dyktandem Bucera, który stał się kluczową postacią niemieckiej reformacji. Wiele razy podejmował przedsięwzięcia mające na celu wypracowanie - najważniejszego dla niego - porozumienia doktrynalnego między Wittenbergą, miastami południowych Niemiec oraz Szwajcarią. Pierwszą sprawą angażującą Bucera było sprecyzowanie pojęcia Eucharystii. Wraz z Melanchtonem odbyli owocne rozmowy w Kassel. Z kolei Luter zaproponował spotkanie w Eisenach, aby zawrzeć pełne porozumienie między protestanckimi frakcjami. Starania Bucera względem południowych Niemiec udały się, ponieważ przekonał ich do udziału, ale za to Szwajcaria, prowadzona przez następcę Zwinglego Heinricha Bullingera, pozostała sceptyczna wobec jego zamiarów. Zamiast tego spotkali się w Bazylei (1536) w celu opracowania własnego wyznania wiary. Byli tam też obecni Bucer i Capito. Wezwali oni Szwajcarów do przyjęcia kompromisowego sformułowania o Eucharystii, które nie obrażało luteranów. Uznano prawdziwą obecność Chrystusa, został natomiast odrzucony zarówno pełny, jak i częściowy związek między Chrystusem

19 Por. A. Burnett, Church discipline and moral reformation in the thought of Martin Bucer, Nebraska 1991, s. 440-451. 
a elementami chleba i wina. Rezultatem była First Helvetic Confession (Confessio Helvetica prior) ${ }^{20}$, której sukces dał Bucerowi pewne nadzieje na zbliżające się spotkanie z Lutrem. Dokument ten uważany był przez wielu teologów reformowanych za zbyt mocno zwrócony w kierunku poglądów ojca reformacji, zwłaszcza dotyczących Wieczerzy Pańskiej ${ }^{21}$.

Spotkanie, przeniesione do Wittenbergi (z powodu choroby Lutra), rozpoczęło się 21 maja 1536 roku. Ku zaskoczeniu południowych Niemców Luter rozpoczął od ataku na nich. Domagał się wyrzeczenia się ich fałszywego rozumienia Eucharystii. Szybko zainterweniował Capito, a Bucer stwierdził, że Luter źle zrozumiał ich poglądy na powyższy temat. Luteranie podkreślali, że niewierzący, którzy uczestniczą w Eucharystii, rzeczywiście przyjmują Ciało i Krew Chrystusa. Z kolei Bucer i południe Niemiec uważali, że otrzymują tylko elementy chleba i wina. Jan Bugenhagen sformułował kompromis zatwierdzony przez Lutra, który odróżniał niegodnych (indigni) od niewierzących (impii). Południe Niemiec uznało, że niegodny przyjmuje Chrystusa, ale pytanie: co niewierzący otrzymuje, pozostało bez odpowiedzi. Następnie obie strony skutecznie pracowały w innych sprawach i w rezultacie podpisano Wittenberger Konkordie $e^{22}$. Strasburg szybko zatwierdził dokument. Bucer przekonał wszystkie południowoniemieckie miasta, zaś szwajcarskie były oporne, w szczególności Zürich. Odrzucili nawet łagodne stwierdzenie sugerujące związek Chrystusa z elementami Eucharystii. Ponadto byli niezadowoleni, że Bucer skłaniał się ku doktrynie rzeczywistej obecności Chrystusa w Eucharystii. Ten polecił Szwajcarii zorganizować krajowy synod, który podjąłby decyzję w tej sprawie. Jednocześnie miał nadzieję, że będzie w stanie przekonać przynajmniej Berno i Bazyleę. Synod odbył się w Zurychu, ale Bucerowi nie udało się pozyskać nawet jednego miasta. Szwajcarzy nigdy nie zaakceptowali ani też nie odrzucili Wittenberger Konkordie ${ }^{23}$.

20 Por. First Helvetic confession, [w:] Martin Bucers Deutsche Schriften, Bd. 6.1, hg. R. Stupperich, Gütersloh 1988, s. 303-388; Reformed confessions of the sixteenth century, dz. cyt., s. 97-111.

${ }_{21}$ Por. M. Bruening, Calvinism's first battleground, Dordrecht 2006, s. 62-70; M. Greschat, Martin Bucer: a reformer and his times, dz. cyt., s. 132-136.

22 Por. Wittenberger Konkordie, [w:] Martin Bucers Deutsche Schriften, Bd. 6.1, dz. cyt., s. 17-190.

${ }_{23}$ Por. J. Kittelson, K. Schurb, The curious histories of the Wittenberg concord, „Concordia Theological Quarterly” 50 (1986), s. 119-137; T. Kaufmann, Wittenberger Konkordie, „Theologische Realenzyklopädie" 36 (2004), s. 243-251. 
Obiektywnie rzecz biorąc, trzeba powiedzieć, że ostateczny wpływ Bucera na Szwajcarię był odczuwalny pośrednio. Zaprosił Jana Kalwina, przyszłego reformatora Genewy, aby poprowadził w Strasburgu francuską wspólnotę uchodźców. Pod kątem teologicznym mieli ze sobą dużo wspólnego i utrzymywali długoletnią przyjaźń. Stopień, w jakim Bucer był pod wpływem Kalwina, jest kwestią otwartą wśród współczesnych uczonych. Jednakże należy zaznaczyć, że wiele reform, które Kalwin później wdrożył w Genewie, w tym liturgia i organizacja kościelna, zostały pierwotnie opracowane w Strasburgu ${ }^{24}$.

Drugą sprawą był problem Żydów. Kiedy wygasło prawo Filipa Heskiego o ochronie Żydów na jego terytorium, Bucer miał za zadanie utworzyć nową politykę wobec nich. Odrzucił jednak tolerancyjny projekt zaproponowany przez Filipa i nałożył na Żydów zakaz wszelkiego dodatkowego handlu. Mogli jedynie prowadzić handel zapewniający im minimum do przeżycia. Judenratschlag ${ }^{25}$ jako pierwszy podawał negatywne stereotypy o Żydach. Rozporządzenie Filipa z 1539 roku stanowiło kompromis: pozwolił on Żydom na uprawianie handlu i rzemiosła, ale zawierał surowe przepisy dotyczące ich współpracy z chrześcijanami. W praktyce nowa polityka wobec Żydów była przerażająca i w rezultacie wielu Żydów zdecydowało się opuścić Hesję. Częściowo winę za taki stan rzeczy ponosił Bucer ${ }^{26}$.

Trzecią kwestią zajmującą Bucera był temat bigamii Filipa Heskiego, w którym polityka reformatora ze Strasburga odnośnie do pragmatycznych rozwiązań problemów okazała się szczególnie kontrowersyjna. Jak wiadomo, wiele razy poparł on Lutra, Bucera i innych reformatorów. Miał jednak poważne problemy małżeńskie i myślał, że słusznie postąpi, rozwodząc się z żoną. Poprosił Bucera, aby opracował teologiczną obronę bigamii, ponieważ zdecydował się zawrzeć bigamiczne małżeństwo. Reformator niechętnie się zgodził, ale postawił warunek, że małżeństwo będzie utrzymywane w tajemnicy. Skonsultował się w tej sprawie z Lutrem i Melanchtonem i powołując się na przykłady starotestamentowych małżeństw poliga-

${ }^{24}$ Por. W. Spijker, Bucer's influence on Calvin: church and community, [w:] Martin Bucer: reforming church and community, ed. D. Wright, Cambridge 2002, s. 32-41.

25 Por. M. Bucer, Judenratschlag, [w:] Martin Bucers Deutsche Schriften, Bd. 7, hg. W. Delius, Gütersloh-Paris 1964, s. 319-361.

26 Por. W. Nijenhuis, Ecclesia Reformata: studies on the Reformation, Leiden 1972, s. 23-37. 
micznych, przekonywał ich do zaaprobowania drugiej żony Filipa. Troje reformatorów przedstawiło Filipowi zalecenie w tej kwestii (Wittenberger Ratschlag ${ }^{27}$ ), a następnie Bucer przedstawił swoje argumenty za i przeciw bigamii. Chociaż dokument określił, że bigamia może zostać ukarana jedynie pod kilkoma warunkami, to Filip przyjął go jako zgodę na małżeństwo z damą dworu jego siostry. Kiedy pogłoski o małżeństwie rozprzestrzeniły się, Luter nakazał Filipowi, aby temu zaprzeczył. z kolei Bucer poradził mu, aby ukrył swoją drugą żonę i tak zataił prawdę. Niektórzy uczeni sugerowali motywację takiego rozwiązania. Teologowie wierzyli, że kłamstwo było usprawiedliwione chęcią ochrony prywatności ich rady. Skandal z małżeństwem spowodował, że Filip zaczął tracić wpływy polityczne, reformacja w cesarstwie była poważnie zagrożona, a reputacja głównych reformatorów znacznie podupadła ${ }^{28}$.

\section{Próby precyzacji zagadnień doktrynalnych na drodze do jedności}

Trzeba podkreślić, że mimo iż Bucer nie był wybitnym teologiem i w sprawach doktryny protestanckiej nie miał gruntownego rozeznania, to jednak jego zaangażowanie $\mathrm{w}$ dysputach z protoplastami reformacji było znaczące. Na krótko przed religijnymi rozmowami w Lipsku zorganizowanymi w celu omówienia programu ewentualnych reform w Księstwie zmarł katolicki książę Saksonii, Jerzy. Elektorat Saksonii wysłał Filipa Melanchtona, a Filip Heski - Marcina Bucera. Księstwo było reprezentowane przez Georga Witzla, byłego luteranina, który ponownie przeszedł na katolicyzm. W dyskusjach (2-7 stycznia 1539 roku) Bucer i Witzel wyrazili zgodę na odroczenie kontrowersyjnych punktów doktryny, ale zgodzili się na piętnaście artykułów dotyczących różnych problemów życia kościelnego. Wycofał się natomiast Melanchton, czując, że doktrynalna jedność stanowiła warunek planu reform. Bucer jednak nie wprowadził żadnych ustępstw doktrynal-

27 Por. Wittenberger Ratschlag, [w:] Corpus Reformatorum, vol. III, New York-London 1963, s. 856-863.

${ }_{28}$ Por. H. Selderhuis, Marriage and divorce in the thought of Martin Bucer, dz. cyt., s. 149-161; M. Brecht, Martin Luther: the preservation of the Church, Minneapolis 1999, s. 206. 
nych: po raz kolejny nie odnosił się do spraw wielkiej wagi dla reformacji, takich jak msza święta i papiestwo. Jego pojednawcze podejście wywołało ostrą krytykę innych reformatorów ${ }^{29}$.

Z kolei Karol V i przywódcy Ligi szmalkaldzkiej w rozejmie frankfurckim (1539) zgodzili się na główne rozmowy dotyczące rozstrzygania wszelkich spraw religijnych w cesarstwie. Bucer głęboko wierzył, że jest możliwe przekonanie większości niemieckich katolików do przyjęcia doktryny sola fide jako podstawy do dyskusji na temat wszystkich innych kwestii. Pod różnymi pseudonimami publikował traktaty promujące niemiecki Kościół narodowy. W dyskusji na spotkaniu w Haguenau (czerwiec 1540) strony nie uzgodniły wspólnego punktu wyjścia i postanowiono ponownie zebrać się w Wormacji. Protestantom przewodził Filip Melanchton, ale Bucer i tak miał duży wpływ na obrady. Kiedy rozmowy znowu nie przyniosły żadnych postępów, cesarski kanclerz Nicholas Perrenot de Granvelle wezwał do tajnych negocjacji. Należy zaznaczyć, że obok promowania wewnątrzwspólnotowej jedności protestanckiej Bucer długi już czas marzył o zniwelowaniu przepaści między protestantami a katolikami. Rozpoczął współpracę z Johannem Gropperem, delegatem arcybiskupa Kolonii Hermanna von Wieda. Zdając sobie sprawę z ryzyka związanego z tego rodzaju oczywistą zmową, zdecydował się budować jedność wśród niemieckich wiernych. Uzgodnione zostały dwa z dwudziestu trzech artykułów; w niektórych zagadnieniach przyznano rację stanowisku katolickiemu. Należą do nich: usprawiedliwienie, sakramenty i organizacja Kościoła. Cztery kwestie sporne pozostały nierozstrzygnięte: kult świętych, msze prywatne, spowiedź uszna i przeistoczenie. Efekty pracy zostały opublikowane w Wormser Buch (Worms Book) ${ }^{30}$, którą zaprezentowano poufnie przedstawicielom z każdej strony religijnego podziału: Filipowi Heskiemu i Joachimowi II, elektorowi Brandenburgii. Księga ta dała podwaliny dla ostatecznych negocjacji między katolikami a protestantami na sejmie w Ratyzbonie w 1541 roku.

29 Por. N. Thompson, Eucharistic Sacrifice and Patristic Tradition in the Theology of Martin Bucer 1534-1546, Leiden 2004, s. 167-172.

30 Por. Wormser Buch, [w:] Martin Bucers Deutsche Schriften, Bd. 9.1, hg. C. Augustijn, Gütersloh 1995, s. 323-483. 
Cesarz Karol, obawiając się inwazji tureckiej na Europę Środkową, chciał przywrócić jedność pomiędzy księstwami Niemiec i stworzył niewielki komitet. Po stronie katolickiej byli Johann Eck, Johann Gropper i Julius von Pflug, a po stronie protestanckiej Filip Melanchthon, Marcin Bucer i Johann Pistorius. Rozmowy prowadzono w oparciu o Regensburger Buch (Regensburg Book) ${ }^{31}$, inaczej mówiąc - Wormser Buch z modyfikacjami naniesionymi przez legata papieskiego, Gaspara Contariniego i innych teologów katolickich. Dla obu stron był to dobry początek: osiągnięto porozumienie w kwestii usprawiedliwienia przez wiarę; nie udało się porozumieć odnośnie do władzy nauczycielskiej Kościoła. Protestanci twierdzili, że jest nią Biblia, katolicy zaś, że to Magisterium, czyli papież i jego biskupi. W artykule na temat mszy i Wieczerzy Pańskiej Gasparo Contarini zamieścił pojęcie transsubstancjacji, która była nie do zaakceptowania przez protestantów. W rezultacie rozmowy stanęły w martwym punkcie. Aby ocalić niektóre z porozumień, Karol i Nicholas Perrenot de Granvelle jeszcze raz wydrukowali Regensburger Buch wraz z dodatkowymi artykułami, w których pozwolono protestantom na przedstawienie swoich opinii. Jednak Luter i papieski trybunał, widząc ten dokument, publicznie odrzucili artykuł o usprawiedliwieniu przez wiarę. Dzieło to miała być dużym krokiem w kierunku unii katolicko-protestanckiej. Trzeba powiedzieć, że niepowodzenie rozmów okazało się poważnym ciosem dla Bucera ${ }^{32}$.

Po powrocie Bucera z Regensburga Strasburg został zaatakowany przez zarazę. Najpierw zachorował jego przyjaciel Wolfgang Capito, a potem zmarła jego żona Elżbieta. W trakcie ostatnich godzin życia zachęciła Bucera, aby po jej śmierci poślubił wdowę po Wolfgangu Capito, Wibrandis Rosenblatt. Bucer spełnił tę prośbę - był czwartym mężem Wibrandis; która przeżyła już Ludwiga Kellera, Jana Oecolampadiusa i Wolfganga Capito. Sprowadziła się do Bucera z czwórką dzieci z poprzednich małżeństw. Obojgu urodziła się córka Elżbieta ${ }^{33}$.

31 Por. Regensburger Buch, [w:] Acta Reformationis catholicae ecclesiam Germaniae, vol. 3.2, hg. F. Pustet, Regensburg 1959, s. 21-88.

32 Por. C. Augustijn, Bucer's ecclesiology in the colloquies with the Catholics, [w:] Martin Bucer: reforming church and community, dz. cyt., s. 107-119; F. Murphy, C. Asprey, Ecumenism today: the universal Church in the 21st century, Hampshire 2008, s. 151-172; D. Fink, Divided by faith: the Protestant doctrine of justification and the confessionalization of biblical exegesis, Durham 2010, s. 280-287.

${ }_{33}$ Por. H. Selderhuis, Marriage and divorce in the thought of Martin Bucer, dz. cyt., s. 122-123. 
Warto zaznaczyć, że poczynania reformatorskie Bucera zataczały coraz większe kręgi. Wraz z Johannem Gropperem (1542) spotkali się z Hermannem von Wiedem, aby omówić wprowadzenie reformy Kościoła w jego archidiecezji. Jako jeden z siedmiu elektorów Świętego Cesarstwa Rzymskiego był kluczową postacią polityczną zarówno dla cesarza, jak i dla reformatorów. Po konsultacji z terytorialnym sejmem zwerbował on Bucera do przeprowadzenia reformy, po czym ten ostatni przeniósł się do Bonn, stolicy elektoratu. Jego wybór spowodował konsternację wśród kapituły kolońskiej katedry. Wrogość duchowieństwa szybko spowodowała rozdźwięk pomiędzy Bucerem a Gropperem. Kapituła złożyła formalny protest przeciwko wyborze Bucera, ale von Wied i tak poparł swojego nowego protegowanego i pozwolono mu pozostać. Choć jego głównym zadaniem było zaplanowanie reformy, to prowadził małą wspólnotę przy katedrze w Bonn, gdzie nauczał trzy razy w tygodniu. Z początkiem 1543 roku Bucer rozpoczął pracę nad głównym dokumentem dla arcybiskupa, Einfältiges Bedenken, worauf eine christliche, im Worte Gottes gegründete Reformation ${ }^{34}$. Z pomocą w sporządzeniu dokumentu przyłączyli się do niego Filip Melanchton i Caspar Hedio. Bucer omówił projekt $\mathrm{z}$ arcybiskupem, a ten po przestudiowaniu dokumentu przedłożył go terytorialnemu sejmowi. Chociaż kapituła katedralna stanowczo go odrzuciła, to sejm orzekł na korzyść programu reform. Dokument końcowy zawierał ponad trzysta stron i obejmował szereg tematów dotyczących doktryny, prawa kościelnego i liturgii: usprawiedliwienie przez wiarę, jedyne ważne sakramenty (chrzest i Wieczerza Pańska), prowadzenie nabożeństw w języku narodowym, udzielanie zezwoleń dla księży do zawarcia małżeństwa.

Jednakże kiedy Karol V wkroczył do miasta ze swoimi oddziałami, zostało wstrzymane wprowadzanie reformy. Był on zaangażowany w ostrą kampanię, żeby utrzymać roszczenia do ziem zdobytych przez Wilhelma, księcia Jülich-Kleve-Berg. Wkrótce potem Bucer został zmuszony do powrotu do Strasburga. Karol stanął po stronie antyreformistów kapituły katedralnej w Kolonii i Uniwersytetu, którzy zaapelowali do niego i do papieża o ochronę przed ich arcybiskupem. Strasburski reformator napisał kilka rozpraw,

34 Por. M. Bucer, F. Melanchton, Einfältiges Bedenken, worauf eine christliche, im Worte Gottes gegründete Reformation, [w:] Martin Bucers Deutsche Schriften, Bd. 11.1, hg. C. Strohm, Gütersloh 1999, s. 147-432. 
broniąc planu reformy von Wieda, w tym sześćsetstronicową Beständige Verantwortung ${ }^{35}$. Nie był jednak w stanie wpłynąć na bieg wydarzeń, a von Wied został ekskomunikowany i formalnie zrzekł się elektorskich tytułów. Wobec widocznej klęski wspólnota Bucera z Bonn z przerażeniem napisała do niego. Zapewnił ich, że chrześcijanie, którzy są pokorni przed Bogiem, ostatecznie otrzymają jego ochronę. Reformator ze Strasburga miał świadomość, że jego pojednawcza działalność wśród protestantów, jak i wobec katolików natrafiła na opór i nie będą dostrzegalne owoce tych przedsięwzięć. Jedynym wyjściem z takiej sytuacji była ofensywa ${ }^{36}$.

Z początkiem wojny szmalkaldzkiej (1546) protestanci zaczęli stopniowy odwrót, Strasburg poddał się armii cesarskiej, a decydujące cesarskie zwycięstwo w bitwie pod Mühlbergiem zakończyło największy protestancki opór. W Strasburgu Bucer oraz jego sojusznicy Mateusz Zell, Paweł Fagius i Jan Marbach nadal naciskali na radę, aby wprowadzono większą dyscyplinę i niezależność od Kościoła. Karol V uchylił ich starania na sejmie w Augsburgu. Sejm opracował prowizoryczny dekret cesarski, Augsburg Interim ${ }^{37}$, który nałożył katolickie obrzędy i ceremonie w cesarstwie, ale z kilkoma ustępstwami wobec reformacji. Aby dokument został przyjęty przez protestantów, Karol potrzebował do jego zatwierdzenia wiodącej postaci wśród reformatorów i zdecydował się na Bucera. Z własnej woli przybył on do Augsburga. Po zaprezentowaniu dokumentu zapowiedział swoją gotowość do jego ratyfikacji, pod warunkiem że zostaną wprowadzone pewne zmiany. Po upływie czasu do negocjacji Karol domagał się jego podpisu. Gdy ten odmówił, został umieszczony w areszcie domowym. Po tygodniu podpisał Interim i został natychmiast zwolniony. Pomimo kapitulacji nadal walczył. Po powrocie do Strasburga zintensyfikował swoje ataki na katolickie obrzędy i ceremonie, publikując Ein Summarischer vergriff der Christlichen Lehre und Religion ${ }^{38}$. Było to oświadczenie wzywające Strasburg

35 Por. M. Bucer, Beständige Verantwortung, [w:] Martin Bucers Deutsche Schriften, Bd. 11.3, hg. T. Wilhelmi, Gütersloh 2006, s. 72-672.

36 Por. A. Burnett, Teaching the Reformation, Oxford 2006, s. 130-134; B. Lugioyo, Martin Bucer's doctrine of justification, Oxford 2010, s. 15-23; M. Greschat, Martin Bucer: a reformer and his times, dz. cyt., s. 185-201.

37 Por. Das Augsburger Interim von 1548, hg. J. Mehlhausen, Neukirchen-Vluyn 1970 (Texte zur Geschichte der Evangelischen Theologie, 3).

38 Por. M. Bucer, Ein Summarischer vergriff der Christlichen Lehre und Religion, [w:] Martin Bucers Deutsche Schriften, Bd. 17, hg. W. Bellardi, Gütersloh 1981, s. 121-150. 
do nawrócenia i bronienia zreformowanych zasad określonych w dwudziestu dziewięciu artykułach. Karol nakazał zniszczyć wszystkie kopie. Napięcie rosło coraz bardziej, a jego oponenci obawiali się, że doprowadzi miasto do katastrofy. Wielu handlowców opuściło Strasburg, aby uniknąć ewentualnego konfliktu z wojskami cesarskimi. Urzędnicy przegłosowali w przeważającej części decyzję, aby rozpocząć negocjację wprowadzenia Interim. Bucer zaapelował, aby Strasburg bezwarunkowo ją odrzucił, bo akceptacja oznaczać będzie krok wstecz. Od 1549 roku, mając wielkie plany wdrożenia Interim w mieście, Bucer i jego współpracownicy wciąż atakowali, tworząc kompendium o tym, jak zachować wiarę protestancką zgodnie z jej wskazaniami. Ostatecznie Bucer i Fagius utracili znaczące wsparcie, co poskutkowało zwolnieniem ich z zajmowanych stanowisk i odwołaniem. Bucer opuścił Strasburg jako uchodźca, podobnie jak przybył tam dwadzieścia pięć lat wcześniej ${ }^{39}$.

\section{Pomoc w reformie angielskiego Kościoła}

Ostatni etap działalności reformatorskiej Bucera oraz prób zjednoczenia był związany z Anglią. Reformator z Strasburga otrzymał kilka ofert azylu, w tym od Melanchtona z Wittenbergi i Kalwina z Genewy. Jednakże przyjął zaproszenie arcybiskupa Canterbury Tomasza Cranmera, aby przyjechać do Anglii i pomóc zreformować angielski Kościół. Bazując na korespondencji z kilkoma znaczącymi Anglikami, głęboko wierzył, że angielska reformacja rozwinie się z oczekiwanym powodzeniem. Najpierw Bucer, Fagius i inni przybyli do Londynu (1549), gdzie Cranmer przywitał ich z pełnymi honorami i wprowadził na dwór króla Edwarda VI. Potem do Bucera dołączyły jego żona Wibrandis i pasierbica, Agnes Capito. Rok później Wibrandis sprowadziła do Anglii resztę swych dzieci i matkę.

Bucer oficjalnie poparł ostrożny program reformy Tomasza Cranmera i Mikołaja Ridleya wobec bardziej radykalnej reformy angielskiego Kościoła głoszonej przez Jana Hoopera i szkockiego reformatora Jana Knoxa. Bucer objął stanowisko królewskiego profesora (Regius Professor of Divinity) na

39 Por. L. Schorn-Schütte, Das Interim 1548/50. Herrschaftskrise und Glaubenskonflikt, Gütersloh 2005; M. Greschat, Martin Bucer: a reformer and his times, dz. cyt., s. 211-225. 
Uniwersytecie w Cambridge. Można wskazać kilka obszarów jego odziaływania. Po pierwsze: włączenie się w polemiki. Pierwszą była ta z Piotrem Martyrem, innym uchodźcą, dyskutującym z katolickimi kolegami nad kwestią Wieczerzy Pańskiej. Poprosił on Bucera o wsparcie, ale ten nie bardzo zgadzał się z jego stanowiskiem. Był zdania, że ukazanie różnic nie przyczyniłoby się do reformy. W sprawie konfliktu wokół kwestii Eucharystii polecił Martyrowi, aby ten nie opowiadał się po żadnej ze stron: ani katolickiej, ani luterańskiej, ani zwinglian. Wciąż był przekonany, że należy z największą gorliwością dążyć do pouczania jak największej rzeszy ludzi w wierze i miłości do Chrystusa, a przy tym nikogo nie obrażać ${ }^{40}$.

Drugą sporną sprawą, z którą w niedługim czasie zetknął się Bucer, był konflikt z udziałem Hoopera, nowego biskupa Gloucester. Odmówił on przywdziania tradycyjnych szat liturgicznych podczas swej konsekracji. Spór o szaty wywołał sprzeciw Cranmera, opowiadającego się za noszeniem typowych szat przez księży, wobec Hoopera, Martyra i Jana Łaskiego, którzy byli odmiennego zdania. Jak wiadomo, Bucer miał zreformować nabożeństwa w Strasburgu, naśladując prostotę pierwotnego Kościoła. Hooper oczekiwał jego wsparcia. Tym razem Bucer starał się nie uczestniczyć w sporze, argumentując, że istnieją ważniejsze kwestie do rozwiązania, takie jak brak duszpasterzy i opieki duszpasterskiej, konieczność katechizmowego nauczania oraz wdrażanie dyscypliny kościelnej. Hooper odmówił zmiany swoich poglądów i został uwięziony w Tower of London do momentu, gdy zgodził się na żądania Cranmera ${ }^{41}$.

Drugim obszarem działania było opracowanie naczelnego traktatu. Trzeba przyznać, że Bucer miał ambitne cele co do reformacji w całej Anglii. Był rozczarowany, ponieważ rządzący nie konsultowali się z nim przy wprowadzaniu zmian. Istniał zwyczaj przedstawiania królowi memorandum każdego nowego roku. Gdy Bucer się o tym dowiedział, pracował już nad swoim głównym traktatem De Regno Christi ${ }^{42}$, którego szkic dał przyjacielowi Janowi Cheke. Dzieło to było kulminacją wielu lat jego przeżyć i doświadczeń, podsumowa-

40 Por. B. Hall, Martin Bucer in England, [w:] Martin Bucer: reforming church and community, dz. cyt., s. 144-152; P. Ayris, D. Selwyn, Thomas Cranmer: churchman and scholar, Woodbridge 1999, s. 199-216.

${ }_{41}$ Por. C. Hopf, Martin Bucer and the English reformation, Oxford 1946, s. 27-34.

42 Por. M. Bucer, De Regno Christi, [w:] Martini Buceri Opera Latina, vol. 15, ed. C. Augustijn, P. Fraenkel, M. Lienhard, Paris 1955. 
niem jego myśli i teologii, które określił jako swoje dziedzictwo. Przekonywał w nim króla Edwarda VI do przejęcia kontroli nad angielską reformacją i proponował, aby parlament wprowadził czternaście zasad reformy, obejmujących sprawy zarówno kościelne, jak i cywilne. Reformacja nie powinna koncentrować się tylko na Kościele, ale na wszystkich dziedzinach życia. Wskazując na trudne warunki socjalne w Anglii, podkreślał rolę diakonów w pomocy biednym i potrzebujących. Z kolei małżeństwo przedstawił jako umowę społeczną, a nie sakrament, dlatego dopuścił rozwód. Opowiedział się za restrukturyzacją systemów gospodarczych i administracyjnych z propozycjami dotyczącymi poprawy przemysłu, rolnictwa i edukacji. Jego idealne społeczeństwo było wyraźnie autorytarne, z silnym naciskiem na chrześcijańską dyscyplinę. Twierdzi, że odnowa człowieka i społeczeństwa ma mieć swoje źródło w głoszeniu prawdziwej Ewangelii i wiernym przylgnięciu do Boga, a Boży wzór życia zawarty jest w Biblii. Jego nowoczesny pomysł uznano za zbyt postępowy jak na tamte czasy. Można powiedzieć, że reforma - według Bucera - ma się realizować przez nawrócenie, poboczność i dyscyplinę. Traktat ten nigdy nie stał się statutem angielskiej reformacji, jak zamierzał Bucer. Nie został on wydrukowany w Anglii, ale w Bazylei, w 1557 roku $^{43}$.

Trzecim, najbardziej dostrzegalnym obszarem działania Bucera w jego wkładzie w reformy w Anglii były uwagi i propozycje do powstającego modlitewnika na dni powszednie i niedziele Book of Common Prayer $^{44}$ - owocu reformowanego Kościoła po zerwaniu z Rzymem. Choć Bucer nie mówił po angielsku, został przez Cranmera poproszony o wskazówki, w jaki sposób można ulepszyć modlitewnik (Censura ${ }^{45}$ ). Bucer dostrzegł w nim luterańskie wpływy i zaproponował uproszczenie liturgii, zauważając mało istotne elementy, takie jak: niektóre święta w kalendarzu liturgicznym, praktyki pobożnościowe, przyklęknięcia i obrzędy, msze prywatne. Skupił się na wspólnocie i na tym, jak ludzie mają sprawować praktyki religijne i się ich uczyć. Król Edward VI wykorzystał w drugiej edycji Prayer Book krytyczne

43 Por. H. Dellar, The influence of Martin Bucer on the English Reformation, „Cahiers D'Histoire Mondiale" 106 (1992), s. 351-356; M. Greschat, Martin Bucer: a reformer and his times, dz. cyt., s. 234245; J. Todd, Reformacja, dz. cyt., s. 340.

44 Por. The Book of Common Prayer: the texts of 1549, 1559, and 1662, Oxford 2011.

45 Por. Censura Martini Buceri super libro sacrorum, [w:] Martini Buceri Scripta Anglicana fere omnia, ed. C. Hubert, Basel 1577, s. 456-503. 
uwagi Bucera, co obraziło konserwatystów w angielskim Kościele, ale i nie usatysfakcjonowało bardziej radykalnych reformatorów. Księga była używana tylko przez kilka miesięcy, bo do śmierci króla w 1553 roku, kiedy to jego przyrodnia siostra Maria przywróciła katolicki kult.

Warto podkreślić, że chociaż nie należy przeceniać oddziaływania Bucera na angielski Kościół, to wywarł on znaczny wpływ na zmiany we wspomnianym modlitewniku. Czas Bucera w Anglii był naznaczony chorobami - reumatyzmem i dolegliwościami jelitowymi oraz ciężką gruźlicą. W lutym 1551 roku stan jego zdrowia załamał się. Wykonawcami swojego testamentu uczynił Waltera Haddona i Matthew Parkera. Wyróżnił w nim swoich bliskich i podziękował swojej pasierbicy Agnes Capito za opiekę nad nim. 28 lutego, po zachęceniu bliskich mu osób, aby wypełnili jego wizję wyrażoną w De Regno Christi, zmarł. Miał 59 lat. Został pochowany w kościele Matki Bożej Większej w Cambridge. Bucer zostawił żonie znaczne dziedzictwo składające się głównie z gospodarstwa domowego i dużych kolekcji książek. Ostatecznie Wibrandis powróciła do Bazylei. Kiedy Maria wstąpiła na tron, próbowała pośmiertnie potępić Bucera i Fagiusa za herezję w ramach swoich wysiłków na rzecz przywrócenia katolicyzmu w Anglii. Ich trumny zostały ekshumowane, a resztki spalone wraz z kopiami ich książek. 22 lipca 1560 roku Elżbieta I formalnie zrehabilitowała obu reformatorów ${ }^{46}$.

\section{Zakończenie}

Po śmierci Marcina Bucera jego pisma nadal były tłumaczone, przedrukowywane i rozpowszechniane w całej Europie. Trzeba zaznaczyć, że nigdy nie określono jego dzieła i próby reformy pojęciem „,bucerian”, prawdopodobnie dlatego, że nigdy nie stworzył teologii systematycznej jak Melanchton dla Kościoła luterańskiego czy Kalwin dla Kościołów reformowanych. Kilka grup, w tym anglikanie, purytanie, luteranie i kalwini, uważało go za jednego z nich.

46 Por. E. Whitaker, Martin Bucer and the Book of Common Prayer, Great Wakering 1974, s. 10173; R. Holder, Crisis and renewal: the era of the Reformations, London 2009, s. 167-187; D. MacCulloch, The later Reformation in England 1547-1603, Basingstoke 2001, s. 14; B. Hall, Martin Bucer in England, dz. cyt., s. 158-159. 
Możliwość przystosowania jego teologii do każdego punktu widzenia była nie do zrealizowania. Jego teologię można określić raczej jako praktyczną i duszpasterską niż teoretyczną. Bucerowi bardziej zależało na dialogu i pozyskaniu swoich przeciwników niż na walce o teoretyczne zagadnienia doktrynalne. Jednocześnie jego teologiczna pozycja była zakorzeniona w warunkach jego czasów, w których wyobrażał sobie idealne społeczeństwo prowadzone przez światłego człowieka, parlament skoncentrowany na Bogu wraz z ludźmi zjednoczonymi w ramach chrześcijańskiej wspólnoty. Bucer dużo i chętnie mówił. Luter nazwał go paplą, cesarz Karol V powiedział, że jest gadułą, a Kalwin stwierdził, że jest zbyt gadatliwy i należy szybko czytać jego prace, jak się ma jeszcze inne sprawy do załatwienia. Jego styl był tak zawiły, że biskup Edmund Grindal mówił, że do jego odczytania konieczny jest magik ${ }^{47}$.

Z jednej strony reformator ze Strasburga odznaczał się wielkim zapałem we wszystkich swoich reformacyjnych dążeniach na rzecz jedności Kościoła nie tylko między różnymi odłamami protestantyzmu, ale również między protestantyzmem a Rzymem. Jego praca rzeczywiście jest godna pochwały, bo - jak zostało wyżej przedstawione - jego ambitna działalność i zaangażowanie obejmowały wiele płaszczyzn odnoszących się do poszczególnych miast czy regionów oraz osób kształtujących ruch reformacyjny. Z drugiej jednak strony jego pragnienie konsensusu nie mogło dojść do skutku z powodu niedopuszczalnego kompromisu, który nie prowadził do jedności, ale do dalszych kłopotów. Jego zaangażowanie we wzajemne porozumienie pozostaje trwałym ostrzeżeniem, aby dążenia do osiągnięcia zwykłej przed zewnętrznej jedności nie odbywało się kosztem prawdy Ewangelii. Krytykowano go za wymijające odpowiedzi na wiele ważnych kwestii i ukrywanie problemów w różnych reformacyjnych sporach. W oparciu o kompromis próbował także dojść do porozumienia z lokalnymi władzami, udzielając im rad i wskazówek, jak należy wprowadzać reformy w mieście. Marcin Bucer jest pamiętany przede wszystkim jako propagator idei pojednania za wszelką cenę w łonie protestantyzmu.

47 Por. M. Greschat, Martin Bucer: a reformer and his times, dz. cyt., s. 247-254; J. Kittelson, Martin Bucer and the ministry of the church, [w:] Martin Bucer: reforming church and community, dz. cyt., s. 83-106; J. Todd, Reformacja, dz. cyt., s. 290. 


\section{Summary}

\section{Martin Bucer as a pioneer of the Reformation reconciliation}

The article concerns the life and work of Martin Bucer, protestant reformer based in Strasbourg. His life was a great attempt to heal the growing rift between the two leading reformers - Martin Luther and Huldrych Zwingli, especially in the Eucharist, and the reconciliation of Protestants and Catholics. He influenced Lutheran, Calvinist, and Anglican doctrines and practices. Bucer was originally a member of the Dominican Order, but then he began to work for the Reformation. He became an ardent admirer of Erasmus, and soon an enthusiastic disciple of Luther. He believed that the catholics could be convinced to join the Reformation. In Strasburg his activities included many sphere of action. He became the chief reformer of the city and was connected with many important religio-political events of the period. Bucer took a new rite of Mass and church discipline. In England, he helped with the reform of the local Church and the new prayer book. He depended more on dialogue and gaining their opponents, rather than fighting for the theoretical issues of doctrine. For a clear statement of doctrine he was always ready to substitute vague formulas in the interest of unity. His ministry did not lead to the formation of a new denomination. He is remembered as an early pioneer of ecumenism.

Keywords: Martin Bucer, English reformation, reformation in Strasbourg, Protestant reconciliation, the Holy Mass

\section{Marcin Bucer jako pionier reformacyjnego pojednania}

Artykuł dotyczy życia i dzieła Marcina Bucera, protestanckiego reformatora związanego ze Strasburgiem. Jego życie było wielką próbą uzdrowienia rosnącej przepaści pomiędzy dwoma czołowymi reformatorami - Marcinem Lutrem i Huldrychem Zwinglim, zwłaszcza w kwestii Eucharystii oraz pojednania protestantów i katolików. Bucer wywarł wpływ na luterańskie, kalwińskie i anglikańskie doktryny i praktyki. Pierwotnie był dominikaninem, ale potem rozpoczął pracę na rzecz reformacji. Stał się zagorzałym wielbicielem Erazma, a wkrótce entuzjastycznym uczniem Lutra. Wierzył, że katolicy mogą przyłączyć się do reformacji. W Strasburgu jego działalność obejmowała wiele sfer. Stał się głównym reformatorem miasta i miał udział w wielu ważnych wydarzeniach religijno-politycznych tego okresu. Bucer zajął się nowym obrzędem mszy i dyscypliny kościelnej. W Anglii pomógł w reformie Kościoła lokalnego i nowego modlitewnika. Bardziej zależało mu na dialogu i pozyskaniu swoich przeciwników niż na walce o teoretyczne kwestie doktrynalne. Dla jasnego określenia doktryny zawsze był gotów 


\section{ks. Wojciech Medwid}

zrezygnować z niejasnej formuły na rzecz jedności. Jego działalność nie doprowadziła do powstania nowego odłamu protestantyzmu. Został zapamiętany jako jeden z pierwszych pionierów ekumenizmu.

Słowa kluczowe: Marcin Bucer, angielska reformacja, reformacja w Strasburgu, protestanckie pojednanie, msza święta

\section{Bibliografia}

Augustijn C., Bucer's ecclesiology in the colloquies with the Catholics, [w:] Martin Bucer: Reforming church and community, ed. D. Wright, Cambridge 2002, s. 107-119.

Ayris P., Selwyn D., Thomas Cranmer: churchman and scholar, Woodbridge 1999.

Brecht M., Martin Luther: the preservation of the Church, Minneapolis 1999, s. 206.

Bruening M., Calvinism's first battleground, Dordrecht 2006.

Bucer M., Beständige Verantwortung, [w:] Martin Bucers Deutsche Schriften, Bd. 11.3, hg. T. Wilhelmi, Gütersloh 2006, s. 72-672.

Bucer M., Confessio Tetrapolitana, [w:] Martin Bucers Deutsche Schriften, Bd. 3, hg. R. Stupperich, Gütersloh-Paris 1969, s. 187-318.

Bucer M., Martini Buceri Opera Latina, vol. 15 De Regno Christi, ed. C. Augustijn, P. Fraenkel, M. Lienhard, Paris 1955.

Bucer M., Ein Summarischer vergriff der Christlichen Lehre und Religion, [w:] Martin Bucers Deutsche Schriften, Bd. 17, hg. W. Bellardi, Gütersloh 1981, s. 121-150.

Bucer M., Grund und Ursach auß gotlicher Schrifft der Neuerungen an dem Nachtmal des Herren so man die Mess nennet, [w:] Martin Bucers Deutsche Schriften, Bd. 1, hg. R. Stupperich, Gütersloh-Paris 1960, s. 194-278.

Bucer M., Judenratschlag, [w:] Martin Bucers Deutsche Schriften, Bd. 7, hg. W. Delius, Gütersloh-Paris 1964, s. 319-361.

Bucer M., Melanchton F., Einfältiges Bedenken, worauf eine christliche, im Worte Gottes gegründete Reformation, [w:] Martin Bucers Deutsche Schriften, Bd. 11.1, hg. C. Strohm, Gütersloh 1999, s. 147-432.

Bucer M., Vergleichnung D. Luthers, und seins gegentheyls, vom Abendmal Christi, [w:] Martin Bucers Deutsche Schriften, Bd. 2, hg. R. Stupperich, Gütersloh-Paris 1962, s. 527-563.

Burnett A., Church discipline and moral Reformation in the thought of Martin Bucer, Nebraska 1991.

Burnett A., Teaching the Reformation, Oxford 2006.

Censura Martini Buceri super libro sacrorum, [w:] Martini Buceri Scripta Anglicana fere omnia, ed. C. Hubert, Basel 1577, s. 456-503.

Collinson P., The Reformation, London 2003.

Das Augsburger Interim von 1548, hg. J. Mehlhausen, [w:] Texte zur Geschichte der evangelischen Theologie 3, Neukirchen-Vluyn 1970.

Dellar H., The influence of Martin Bucer on the English Reformation, „Cahiers D'Histoire Mondiale" 106 (1992), s. 351-356.

Edwards M., Luther and the False Brethren, Standford 1975. 
Eire C., War against the idols, Cambridge 1989.

Fink D., Divided by faith: the Protestant doctrine of justification and the confessionalization of biblical exegesis, Durham 2010.

First helvetic confession, [w:] Martin Bucers Deutsche Schriften, Bd. 6.1, hg. R. Stupperich, Gütersloh 1988, s. 303-388.

Greschat M., Martin Bucer: a reformer and his times, Kentucky 2004.

Hall B., Martin Bucer in England, [w:] Martin Bucer: reforming church and community, ed. D. Wright, Cambridge 2002, s. 144-152.

Holder R., Crisis and renewal: the era of the reformations, London 2009.

Hopf C., Martin Bucer and the English Reformation, Oxford 1946.

Hughes M., Early modern Germany, London 1992.

Kaufmann T., Wittenberger Konkordie, [w:] Theologische Realenzyklopädie, Bd. 36, hg. G. Krause, G. Müller, Berlin-New York 2004, s. 243-251.

Kittelson J., Martin Bucer and the ministry of the church, [w:] Martin Bucer: reforming church and community, ed. D. Wright, Cambridge 2002, s. 83-106.

Kittelson J., Schurb K., The curious histories of the Wittenberg concord, „Concordia Theological Quarterly" 50 (1986), s. 119-137.

Krieger C., Martin Bucer and sixteenth century Europe, Leiden 1993.

Lawrence D., Martin Bucer: unsung hero of the Reformation, Nashville 2008.

Lugioyo B., Martin Bucers doctrine of justification, Oxford 2010.

Luther M., Vom Abendmahl Christi, Bekenntnis, [w:] M. Luther, Martin Luthers Werke. Kritische Gesammtausgabe, Bd. 26, Weimar 1883-1929, s. 261-509.

MacCulloch D., Reformation: Europe's house divided, London 2003.

MacCulloch D., The later Reformation in England 1547-1603, Basingstoke 2001.

Martini Buceri Apologia qua fidei suae atque doctrinae, [w:] Martin Bucers Deutsche Schriften, Bd. 2, hg. R. Stupperich, Gütersloh-Paris 1962, s. 452-524.

Melanchton F., Confessio Augustana, [w:] Die Bekenntnisschriften der evangelisch-lutherischen Kirche, hg. im Gedenkjahr der Augsburgischen Konfession 1930, Göttingen 1998, s. 31-137.

Murphy F., Asprey C., Ecumenism today: the universal Church in the $21^{\text {st }}$ century, Hampshire 2008.

Nijenhuis W., Ecclesia reformata: studies on the Reformation, Leiden 1972, s. 23-37.

Reformed confessions of the sixteenth century, ed. A. Cochrane, J. Rogers, London 2003, s. 51-88.

Regensburger Buch, [w:] Acta Reformationis catholicae ecclesiam Germaniae, vol. 3.2, hg. F. Pustet, Regensburg 1959, s. 21-88.

Schorn-Schütte L., Das Interim 1548/50. Herrschaftskrise und Glaubenskonflikt, Gütersloh 2005.

Selderhuis H., Marriage and divorce in the thought of Martin Bucer, Missouri 1999.

Spijker W., Bucer's influence on Calvin: church and community, [w:] Martin Bucer: reforming church and community, ed. D. Wright, Cambridge 2002, s. 32-41.

The Book of Common Prayer: The Texts of 1549, 1559, and 1662, Oxford 2011.

Thompson N., Eucharistic sacrifice and patristic tradition in the theology of Martin Bucer 1534-1546, Leiden 2004. 
Todd J., Reformacja, przekł. T. Szafrański, Warszawa 1974.

Whitaker E., Martin Bucer and the Book of Common Prayer, Great Wakering 1974.

Wittenberger Konkordie, [w:] Martin Bucers Deutsche Schriften, Bd.6.1, hg. R. Stupperich, Gütersloh 1988, s. 17-190.

Wittenberger Ratschlag, [w:] Corpus Reformatorum, vol. 3, New York-London 1963, s. 856-863.

Wormser Buch, [w:] Martin Bucers Deutsche Schriften, Bd. 9.1, hg. C. Augustijn, Gütersloh 1995, s. 323-483. 